Available online on 15.04.2020 at http://jddtonline.info
Open Access to Pharmaceutical and Medical Research
unrestricted non-commercial use, provided the original work is properly cited

Open $\odot$ Access

Research Article

\title{
Biochemical and Toxicological Evaluations of Aqueous Extract of Parquetina nigrescens (Afzel.) leaves on Mifepristone-induced Polycystic Ovarian Syndrome in Rats
}

Femi-olabisi Fehintoluwa Joy*1, Faokunla Opeyemi², Agboola Anthonia Oluyemi ${ }^{3}$, Olorunyolemi Imoleayo Moses

1 Biochemistry Unit, Department of Biological Sciences, Mountain Top University, Ogun, Nigeria

2 Department of Biochemistry, Federal University Lokoja, Kogi State, Nigeria

${ }^{3}$ Biochemistry Unit, Department of Biological Sciences, Wesley University Ondo, Nigeria

\begin{abstract}
The biochemical and toxicological effects of aqueous extract of Parquetina nigrescens leaves (AEPNL) at the doses of 50, 100, and 200 mg/kg body weight on mifepristone-induced in Polycystic Ovarian Syndrome (PCOS) was investigated in female Wistar rats. Sixty female Wistar rats $(190.00 \pm 13.00 \mathrm{~g})$ were assigned into 6 groups $(\mathrm{A}-\mathrm{F})$ of ten each: animals in group A received $0.5 \mathrm{ml}$ of distilled water orally on daily basis for 30 days while the mifepristonized rats in groups B, C, D and E also received orally $0.5 \mathrm{ml}$ of distilled water, $7.14 \mathrm{mg} / \mathrm{kg}$ of $\mathrm{metformin}$ (reference drug) and same volume of the extract corresponding to 50,100, and $200 \mathrm{mg} / \mathrm{kg}$ body weight of AEPNL respectively after which levels of some biochemical and toxicological indices were determined. AEPNL aggravated mifepristone-treatment related increases in albumin, total protein and liver aspartate aminotransferase activity and mitigated the increases in globulin, total bilirubin, urea, creatinine, liver and serum alkaline phosphatase and alanine aminotransferase activities, and no treatment-related histoarchitectural changes occurred in the liver, kidney and uterus of the female rats. Therefore, the aqueous extract of Parquetina nigrescens leaves attenuated and also aggravated some biochemical parameters in the serum, liver and kidney but with no histological changes in the liver, kidney and uterus of the mifepristonized female Wistar rats.
\end{abstract}

Keywords: Mifepristone, toxicology, Parquetina nigrescens, Polycystic Ovarian Syndrome, histology

Article Info: Received 05 Feb 2020; $\quad$ Review Completed 18 March 2020; $\quad$ Accepted 29 March 2020; Available online 15 April 2020

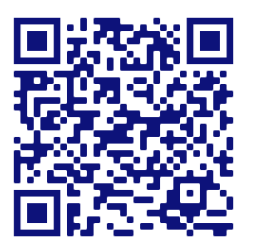

\section{Cite this article as:}

Femi-olabisi FJ, Faokunla 0, Agboola AO, Olorunyolemi IM, Biochemical and Toxicological Evaluations of Aqueous Extract of Parquetina nigrescens (Afzel.) leaves on Mifepristone-induced Polycystic Ovarian Syndrome in Rats, Journal of Drug Delivery and Therapeutics. 2020; 10(2-s):94-101 http://dx.doi.org/10.22270/jddt.v10i2-s.3956

*Address for Correspondence:

Femi-olabisi Fehintoluwa Joy, Biochemistry Unit, Department of Biological Sciences, Mountain Top University, Ogun, Nigeria

\section{INTRODUCTION}

Medicinal plants are important elements of indigenous medical system in all countries of the world [1]. The general acceptability of phytomedicines is, however, limited by lack of dose regimen and adequate toxicity or safety [2]. Polycystic ovarian syndrome (PCOS), which was formally called Stein-Leventhal syndrome or functional ovarian hyperandrogenism, is a disorder that is characterised by chronic anovulation [3], enlarged ovaries containing follicular cysts at different stages of growth, atresia and clinical and/or biochemical evidence of ovarian hyperandrogenism. PCOS is thought to be one of the leading causes of female subfertility [4]. Many plants with hypoglycaemic and anti-obesity activities have also been reported to be used in the management of PCOS [5]. It has been reported over the years that the leaf decoctions of $P$. nigrescens have been used for the treatment of gonorrhea and menstrual disorders [6]. The current therapeutic approach to treating PCOS involves use of insulin sensitizers such as metformin and letrozole, since the central core of PCOS etiologies is through insulin resistance. Other therapeutic agents that have been used to manage PCOS includes metformin, clomiphene citrate, tamoxifen and troglitazone [7] [8]. Plant extracts as potential phytotherapeutic products are supposed to be safe. However, adverse and untoward fatal effects have been reported on plant such as, Parquetina nigrescens [9]. Toxicity associated with herbal products [10] [11] has alerted many national [12] and international regulatory authorities [13] to develop and implement various sets of guidelines for assessing, monitoring, and preventing the toxicity associated with such herbal products [14]. Toxicity tests are most widely used to examine specific adverse events or specific endpoints [15] such as cancer, cardiotoxicity and skin/eye 
irritation, etc. Therefore, toxicological evaluation of this botanicals with fertility-enhancing activity to ascertain their safety as oral remedies in normal experimental animals and those induced with the PCOS condition is thus, needed to increase their acceptability.

Parquetina nigrescens (Afzel.) Bullock also known as Ogbo (yoruba), Kwankwanin (Hausa) and Mgbidim gbe (Igbo), is a shrub that is commonly found in West African countries especially Nigeria and Ghana [16] [17]. It is an herbaceous, perennial twine belonging to the family Asclepiadaceae. It is usually woody at the base with 7-8 m in length [19] [20]. Parquetina nigrescens have been investigated scientifically for quite a number of pharmacological activities. Agbor and Odetola, [20] reported that the aqueous extract of $P$. nigrescens leaves increased the red blood cell count of anaemic rats. Kayode and Yakubu [21] reported that the aqueous extract of $P$. nigrescens leaves restored both physical and biochemical indices of male sexual activity/competence via changes in reproductive hormones in paroxetin-induced sexually dysfunction rats. Saba et al., [22] also reported that $P$. nigresence exhibited antidiabetic and antihyperlipidemic activity. Furthermore, Agbor and Odetola [20] concluded that the plant has modulatory effect on the haematological parameters of mice whereas it exhibited both cardiotonic and sympathomimetic effects in rats [23].

Despite all these studies, there has not been any report, in the open scientific literature that has addressed the toxicity of the aqueous extract of $P$. nigrescens leaves in mifepristone-induced PCOS female rats. Therefore, the present study was aimed at investigating the safety/toxicity risk of aqueous extract of $P$. nigrescens leaves on mifepristone-induced PCOS in female rats.

\section{MATERIAL AND METHODS}

\section{Plant Material}

The leaves of Parquetina nigrescens were obtained from the premises of Wesley University, Ondo, Nigeria. The plant was authenticated at the Department of Plant Biology, University of Ilorin, Ilorin, Nigeria. A voucher specimen (UIH 001/0980) was deposited at the Herbarium of the Department.

\section{Animals}

Sixty, healthy, female Wistar rats (190.00 $\pm 13.00 \mathrm{~g})$ obtained from the animal holding Unit of the Department of Physiology, University of Ibadan, Ibadan, Nigeria. The animals were kept in a well-ventilated house condition (temperature: $22 \pm 3^{\circ} \mathrm{C}$; photoperiod: $12 \mathrm{~h} / 12 \mathrm{~h}$ light/dark cycle; humidity: 45-50 \%) and fed with rat pellets (Vital Feeds, Grand Cereals, Jos, Nigeria) and water ad libitum.

\section{Drugs, Assay Kits, and Chemicals}

Albumin, bilirubin, aspartate aminotransferase (AST), alanine aminotransferase (ALT), urea, uric acid, creatinine and protein assay kits were products of Randox Laboratory, Co-Atrim, United Kingdom. Mifepristone was a product of Ranbaxy Laboratories Limited, New Delhi, India. Pure olive oil was a product of Andalu-Cia, Goya en Espana, Sevilla, Spain. All other reagents used were from Sigma Chemicals, St. Louis, USA.

\section{Preparation of Extract}

A known weight (3 kg) of Parquetina nigrescens leaves was washed, air-dried and pulverized in a blender (Mikachi Blender, Model MK-1830, China). The powdered material (1 $\mathrm{kg}$ ) was extracted in $5 \mathrm{~L}$ of distilled water for 48 hours and filtered with Whatman No. 1 filter paper. The filtrate was lyophilized to give a yield of $118.01 \mathrm{~g}$ which corresponded to $11.80 \%$. The resulting powder was reconstituted in distilled water to obtain the doses of 50,100, $200 \mathrm{mg} / \mathrm{kg}$ body weight used in this study.

Animal grouping and extract administration for pharmacological study

A total of 60 female rats that was acclimatized for 2 weeks and were completely randomized into six groups of ten (10) animals each. PCOS was induced in forty female Wistar rats in groups designated B - F with $10 \mathrm{mg}$ of mifepristone as described by Yakubu et al. [24]. The extract administration according to the groups was carried out as follows:

Group A (non-PCOS-induced control) received $0.5 \mathrm{ml}$ of distilled water

Group B (PCOS-induced) received $0.5 \mathrm{ml}$ of distilled water

Group C (PCOS-induced) received $7.14 \mathrm{mg} / \mathrm{kg}$ body weight of metformin (Reference drug

Group D (PCOS-induced) received $50 \mathrm{mg} / \mathrm{kg}$ body weight of aqueous extract of Parquetina nigresens leaves

Group E (PCOS-induced) received $100 \mathrm{mg} / \mathrm{kg}$ body weight of aqueous extract of Parquetina nigresens leaves

Group F (PCOS-induced) received $200 \mathrm{mg} / \mathrm{kg}$ body weight of aqueous extract of Parquetina nigresens leaves

The $0.5 \mathrm{ml}$ of the plant extract and distilled water which corresponded to their respective doses were administered once daily for thirty days. At the end of the experimental period, the animals were anesthesized using diethyl ether and sacrificed by jugular puncture. Thereafter, the uterus, liver and kidney were isolated and separately fixed in $10 \%$ formalin for histological studies.

\section{Preparation of Serum and Tissue Supernatants}

The method described by Yakubu et al. [25] was used to prepare the serum and tissue supernatant. The rats were weighed individually and thereafter anaesthesized in a jar containing cotton wool soaked in diethyl ether. The neck area was cleared of fur and skin to expose the jugular veins. The jugular veins were displaced slightly from the neck region and thereafter cut with a sharp sterile blade. The animals were held head downwards, allowed to bleed into clean, dry centrifuge tubes and left at room temperature for 10 minutes to clot. The blood samples were centrifuged at $1000 \times g$ for 15 minutes using Uniscope Laboratory Centrifuge (Model SM800B, Surgifield Medicals, Davon, England). The sera were thereafter aspirated using Pasteur pipette into clean, dry, sample bottles and were then stored frozen $\left(4^{\circ} \mathrm{C}\right)$ overnight. The animals were quickly dissected, the liver, kidney, uterus and ovary were excised, cleaned of fatty layers, weighed and transferred into ice cold $0.25 \mathrm{M}$ sucrose solution. Thereafter, each organ were blotted with blotting paper, cut thinly with a sterile blade and homogenized separately in ice cold $0.25 \mathrm{M}$ sucrose solution $(1: 5 \mathrm{w} / \mathrm{v})$. The homogenates obtained were centrifuged at $503 \times g$ for 15 minutes to obtain the supernatants which were then gently collected into sample bottles, stored frozen $\left(4^{\circ} \mathrm{C}\right)$ overnight before being used for the various biochemical assays.

\section{Determination of Biochemical Parameters}

The concentrations of albumin, globulin, total and conjugated bilirubin, urea, uric acid, creatinine, ALP, , AST, and ALT were determined by adopting standard procedures [26]. 


\section{Histopathological Examination}

The organs of interest (liver, kidney and uterus) were fixed in $10 \%(\mathrm{v} / \mathrm{v})$ formaldehyde and processed as described by Krause [27], while tissue sectioning was done according to the procedure described by Drury and Wallington [28] and stained with hematoxylin/ eosin (H and E). Photomicrographs of the liver, kidney, ovaries and uterus were captured at $\times 400$ with a light microscope connected to a computer with Presto! Image Folio package software (Newsoft Technology Corporation, USA).

\section{Statistical Analysis}

Data were expressed as the mean \pm standard error mean of ten determinations and data were analysed for statistical significant at $\mathrm{P}<0.05$ using One Way Analysis of Variance and Duncan Multiple Range Test performed with Statistical Package for Social Sciences, version 18.0 (SPSS Inc., Chicago, USA).

\section{RESULTS}

Mifepristone administration significantly $(\mathrm{p}<0.05)$ increased the serum albumin, globulin, total bilirubin and total protein. In contrast, serum conjugated bilirubin and Creatinine of mifepristone-treated animals was significantly $(p<0.05)$ decreased when compared with the control female rats (Table 1). The serum urea and uric acid levels of mifepristone-treated female rats compared favourably $(p>0.05)$ with control animals (Table 1).All the doses of the extract administered significantly $(\mathrm{p}<0.05)$ increased the serum albumin, total bilirubin and total protein of mifepristonized rats whereas the serum globulin and creatinine were significantly $(\mathrm{p}<0.05)$ decreased compared to the control group. However, the reference drug administered to mifepristonized rats significantly $(\mathrm{P}<0.05)$ increased the serum albumin, total protein and uric acid whereas the serum globulin, total and conjugated bilirubin content decreased significantly when compared with the control rats (Table 1). The serum urea concentration of mifepristonized rats administered the reference drug and 50 $\mathrm{mg} / \mathrm{kg}$ body of AEPNL compared favourably ( $p>0.05$ ) with control animals whereas 100 and $200 \mathrm{mg} / \mathrm{kg}$ body of AEPNL significantly $(\mathrm{P}<0.05)$ elevated urea concentration of mifepristonized rats (Table 1). The administration of 50 and $200 \mathrm{mg} / \mathrm{kg}$ body of AEPNL to mifepristonized rats did not alter the conjugated bilirubin concentration whereas 100 $\mathrm{mg} / \mathrm{kg}$ body of the extract significantly $(\mathrm{P}<0.05)$ decreased serum conjugated bilirubin content of mifepristonized rats when compared with control rats (Table 1).

The administration of 50 and $200 \mathrm{mg} / \mathrm{kg}$ body weight of the extract to mifepristone-treated rats significantly $(\mathrm{P}<0.05)$ increased the ALP activity in the kidney in a manner similar to mifepristone-treated rats that were administered 7.14 $\mathrm{mg} / \mathrm{kg}$ body weight of metformin. Again, the administration of $100 \mathrm{mg} / \mathrm{kg}$ body weight of the extract to mifepristonetreated rats significantly $(\mathrm{P}<0.05)$ decreased the ALP activity in the kidney when compared with the animals that were administered metformin (Table 2).

However, administration of mifepristone significantly $(\mathrm{P}<0.05)$ decreased alkaline phosphatase (ALP) activity in the liver and serum of animals whereas it significantly increased $(\mathrm{P}<0.05)$ the kidney enzyme when compared with the control female rats (Table 2). The ALP activity in the liver of mifepristonized animals administered all the doses of the extract was significantly $(\mathrm{P}<0.05)$ increased when compared to the animals that received metformin (Table 2). The ALP activity in the serum of mifepristone-treated animals administered 100 and $200 \mathrm{mg} / \mathrm{kg}$ body weight of the extract was not significantly different $(P>0.05)$ when compared to the animals that received metformin whereas the $50 \mathrm{mg} / \mathrm{kg}$ body weight of the extract significantly $(\mathrm{P}<0.05)$ decreased the ALP activity in the serum of the animals (Table 2).

The alanine aminotransferase (ALT) activity in the liver and serum of the rats administered mifepristone was not significantly different $(p>0.05)$ when compared to the control female rats. Futhermore, administration of all the doses of the extract to mifepristonized rats significantly $(\mathrm{P}<0.05)$ reduced the ALT activity in the liver when compared with animals given metformin, (Table 3). Again, administration of 50 and $100 \mathrm{mg} / \mathrm{kg}$ body weight of the extract to mifepristonized rats significantly $(\mathrm{P}<0.05)$ increased the ALT activity in the serum when compared with the animals administered metformin. The serum ALT activity of mifepristone-treated rats that received 200 $\mathrm{mg} / \mathrm{kg}$ body weight of the extract was significantly $(\mathrm{P}<0.05)$ decreased when compared with animals given metformin (Table 3). Mifepristone administration to animals significantly $\quad(\mathrm{p}<0.05)$ reduced the aspartate aminotransferase (AST) activity in the liver whereas AST activity was not significantly different $(p>0.05)$ in the serum when compared with the olive oil-treated female rats. Again, administration of all the doses of the extract to mifepristonized rats significantly $(\mathrm{p}<0.05)$ reduced the AST activity in the liver. The activity of AST in mifepristonized rats that received $7.14 \mathrm{mg} / \mathrm{kg}$ of metformin was significantly $(p<0.05)$ increased when compared to the olive oil-treated female rats (Table 3). Furthermore, administration of 50 and $100 \mathrm{mg} / \mathrm{kg}$ body weight of the extract to mifepristonetreated rats significantly $(\mathrm{P}<0.05)$ increased the serum AST activity in a manner similar to animals that received metformin. However, the serum AST activity of mifepristonized animals administered $200 \mathrm{mg} / \mathrm{kg}$ body weight of the extract was significantly decreased when compared $(\mathrm{P}<0.05)$ with the metformin treated rats (Table 3).

The architecture of the liver and kidney was normal at the cellular level in distilled water treated control animals (Plate 1 and 7 respectively). The liver and kidney histoarchitecture of female animals administered mifepristone was intact (Plate 2 and 8 respectively). Administration of 50, 100 and $200 \mathrm{mg} / \mathrm{kg}$ body weight of the extract and metformin to mifepristonized animals revealed the histoarchtecture of kidney have normal glomeruli and proximal and distal convoluted tubules (Plates 9-12). The liver architecture of mifepristonized administered animals 50, 100 and 200 $\mathrm{mg} / \mathrm{kg}$ body weight of the extract and metformin was normal having hepatocytes with no evidence of adhesion or inflammation (Plates 3-6).

The uterine histoarchitecture of distilled water treated control animals were in normal proliferative phase. The administration of mifepristone to female animals did not distort uterine architecture. Furthermore, mifepristonized female rats administered all the doses of the extract and metformin had normal uterine epithelium lining. The mifepristonized animals administered $50 \mathrm{mg} / \mathrm{kg}$ body weight of the extract had short cuboidal lining epithelium in its histoarchitecture (Plates 13-18). 
Table 1: Effect of aqueous extract of Parquetina nigresens leaves on some liver and kidney function parameters of PCOS rats

\begin{tabular}{|c|c|c|c|c|c|c|}
\hline Serum parameter & Control & $\begin{array}{l}\text { MFP + } \\
\text { distilled } \\
\text { water }\end{array}$ & $\begin{array}{l}\text { MFP + } \\
\text { Metformin } \\
(7.14 \\
\text { mg/kg } \\
\text { body } \\
\text { weight) }\end{array}$ & $\begin{array}{l}\text { MFP + } \\
50 \mathrm{mg} / \mathrm{kg} \\
\text { body weight } \\
\text { of extract }\end{array}$ & $\begin{array}{l}\text { MFP + } \\
100 \mathrm{mg} / \mathrm{kg} \\
\text { body weight } \\
\text { of extract }\end{array}$ & $\begin{array}{l}\text { MFP + } \\
200 \mathrm{mg} / \mathrm{kg} \\
\text { body weight } \\
\text { of extract }\end{array}$ \\
\hline Albumin (g/dl) & $2.16 \pm 0.60^{\mathrm{a}}$ & $4.33 \pm 0.39 \mathrm{~b}$ & $5.61 \pm 0.53^{c}$ & $6.32 \pm 0.41^{c}$ & $6.55 \pm 0.33^{c}$ & $11.83 \pm 0.58^{\mathrm{d}}$ \\
\hline Globulin (g/dl) & $7.39 \pm 0.61^{a}$ & $7.90 \pm 2.44 \mathrm{~b}$ & $5.12 \pm 1.00^{c}$ & $4.26 \pm 0.89 c$ & $3.35 \pm 1.13^{c}$ & $5.13 \pm 0.59 c$ \\
\hline $\begin{array}{l}\text { Total Bilirubin } \\
(\mu \mathrm{mol} / \mathrm{L})\end{array}$ & $1.39 \pm 0.05^{\mathrm{a}}$ & $1.64 \pm 0.06^{b}$ & $0.57 \pm 0.09 \mathrm{~d}$ & $1.68 \pm 0.10^{\mathrm{b}}$ & $1.49 \pm 0.08^{b}$ & $2.13 \pm 0.04^{c}$ \\
\hline $\begin{array}{l}\text { Conjugated Bilirubin } \\
(\mu \mathrm{mol} / \mathrm{L})\end{array}$ & $3.04 \pm 0.59 a$ & $2.13 \pm 0.31^{b}$ & $1.84 \pm 0.22^{c}$ & $2.39 \pm 0.25^{a}$ & $1.94 \pm 0.18^{c}$ & $3.33 \pm 0.24^{\mathrm{a}}$ \\
\hline Total protein $(\mathrm{mg} / \mathrm{ml})$ & $8.67 \pm 0.17 \mathrm{a}$ & $12.23 \pm 2.44 \mathrm{~b}$ & $11.19 \pm 1.08^{\mathrm{b}}$ & $10.08 \pm 0.40 c$ & $10.04 \pm 1.10^{c}$ & $16.66 \pm 2.46^{d}$ \\
\hline Urea (mg/dl) & $9.14 \pm 0.60^{\mathrm{a}}$ & $9.29 \pm 0.54^{\mathrm{a}}$ & $9.41 \pm 0.31^{\mathrm{a}}$ & $9.24 \pm 0.44^{a}$ & $13.11 \pm 0.39 \mathrm{~b}$ & $7.50 \pm 0.34^{c}$ \\
\hline Uric acid (mg/dl) & $2.24 \pm 0.38^{\mathrm{a}}$ & $2.16 \pm 0.31^{\mathrm{a}}$ & $3.14 \pm 0.21^{b}$ & $2.47 \pm 0.33^{a}$ & $2.77 \pm 0.36^{\mathrm{a}}$ & $1.37 \pm 0.24^{c}$ \\
\hline Creatinine & $9.55 \pm 0.00^{a}$ & $4.64 \pm 0.51^{b}$ & $5.46 \pm 0.00^{\mathrm{b}}$ & $6.46 \pm 0.90^{\mathrm{b}}$ & $3.36 \pm 0.42^{\mathrm{b}}$ & $3.73 \pm 1.29 \mathrm{~b}$ \\
\hline
\end{tabular}

Data are means of ten determinations \pm SEM. Values with different superscripts in each column are significantly different $(\mathrm{P}<0.05)$; MFP- Mifepristone

Table 2: Effects of aqueous extract of $P$. nigrescens leaves on the alkaline phosphatase activity of the liver, kidney and serum of PCOS rats

\begin{tabular}{|c|c|c|c|c|c|c|}
\hline Parameter & Control & $\begin{array}{l}\text { MFP + } \\
\text { distilled } \\
\text { water }\end{array}$ & $\begin{array}{l}\text { MFP + } \\
\text { Metformin } \\
\text { (7.14 mg/kg } \\
\text { body weight) }\end{array}$ & $\begin{array}{l}\text { MFP + } \\
50 \mathrm{mg} / \mathrm{kg} \\
\text { body weight } \\
\text { of extract }\end{array}$ & $\begin{array}{l}\text { MFP + } \\
100 \mathrm{mg} / \mathrm{kg} \\
\text { body weight } \\
\text { of extract }\end{array}$ & $\begin{array}{l}\text { MFP + } \\
200 \mathrm{mg} / \mathrm{kg} \\
\text { body weight } \\
\text { of extract }\end{array}$ \\
\hline Kidney ALP & $58.11 \pm 0.93^{a}$ & $136.94 \pm 0.58^{c}$ & $223.79 \pm 1.43^{\mathrm{e}}$ & $199.93 \pm 0.84 \mathrm{~d}$ & $94.04 \pm 6.26^{b}$ & $141.14 \pm 6.68^{c}$ \\
\hline Liver ALP & $51.45 \pm 3.08^{a}$ & $5.67 \pm 0.23^{e}$ & $22.61 \pm 0.95^{d}$ & $38.13 \pm 1.10^{c}$ & $33.65 \pm 2.65^{c}$ & $41.28 \pm 0.13^{b}$ \\
\hline Serum ALP & $25.26 \pm 1.29 \mathrm{a}$ & $24.02 \pm 0.93^{b}$ & $26.53 \pm 1.15^{c}$ & $19.55 \pm 0.44 \mathrm{~d}$ & $27.02 \pm 0.10^{c}$ & $25.65 \pm 1.57 c$ \\
\hline
\end{tabular}

Data are means of ten determinations \pm SEM. Values with different superscripts in each column are significantly different $(\mathrm{P}<0.05)$; MFP- Mifepristone, ALP- Alkaline phosphatase

Table 3: Effect of aqueous extract of Parquetina nigrescens leaves on the aminotransferase activity in the liver and serum of PCOS rats

\begin{tabular}{|c|c|c|c|c|c|c|}
\hline Parameter & Control & $\begin{array}{l}\text { MFP + } \\
\text { distilled } \\
\text { water }\end{array}$ & $\begin{array}{l}\text { MFP + } \\
\text { Metformin } \\
\text { ( } 7.14 \text { mg/kg } \\
\text { body weight) }\end{array}$ & $\begin{array}{l}\text { MFP + } \\
50 \mathrm{mg} / \mathrm{kg} \\
\text { body weight } \\
\text { of extract }\end{array}$ & $\begin{array}{l}\text { MFP + } \\
100 \mathrm{mg} / \mathrm{kg} \\
\text { body weight } \\
\text { of extract }\end{array}$ & $\begin{array}{l}\text { MFP + } \\
200 \mathrm{mg} / \mathrm{kg} \\
\text { body weight } \\
\text { of extract }\end{array}$ \\
\hline Liver ALT & $45.34 \pm 3.71^{\mathrm{a}}$ & $36.77 \pm 4.09^{a}$ & $47.83 \pm 1.96^{b}$ & $27.24 \pm 4.56^{\mathrm{d}}$ & $27.41 \pm 2.98^{\mathrm{d}}$ & $14.56 \pm 1.68^{c}$ \\
\hline Serum ALT & $4.13 \pm 0.52^{\mathrm{a}}$ & $3.91 \pm 0.51^{\mathrm{a}}$ & $4.11 \pm 0.38^{a}$ & $4.80 \pm 0.51^{b}$ & $5.20 \pm 0.64 \mathrm{~b}$ & $3.38 \pm 0.70^{a}$ \\
\hline Liver AST & $118.27 \pm 16.58^{a}$ & $55.72 \pm 2.16^{c}$ & $169.33 \pm 5.38^{b}$ & $51.75 \pm 3.82^{c}$ & $37.37 \pm 4.04^{c}$ & $88.27 \pm 2.78^{c}$ \\
\hline Serum AST & $2.55 \pm 0.23^{a}$ & $2.10 \pm 0.45^{\mathrm{a}}$ & $3.05 \pm 0.54 b$ & $4.39 \pm 0.78^{b}$ & $3.17 \pm 0.66^{b}$ & $1.81 \pm 0.26^{\mathrm{a}}$ \\
\hline
\end{tabular}

Data are means of ten determinations \pm SEM. Values with different superscripts in each column are significantly different $(\mathrm{P}<0.05)$; MFP- Mifepristone, ALT-Alanine aminotransferase, AST- Aspartate aminotransferase 


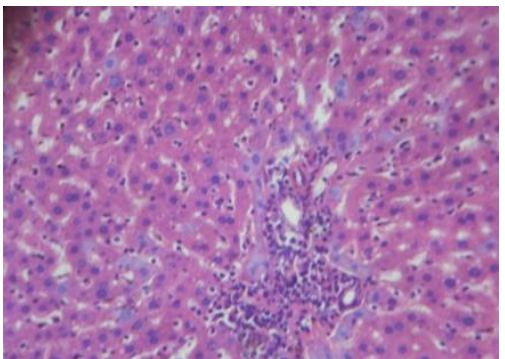

Plate 1: Cross section of the liver of female rats administered distilled water the (control) $(\times 40 ; \mathrm{H} \& \mathrm{E})$

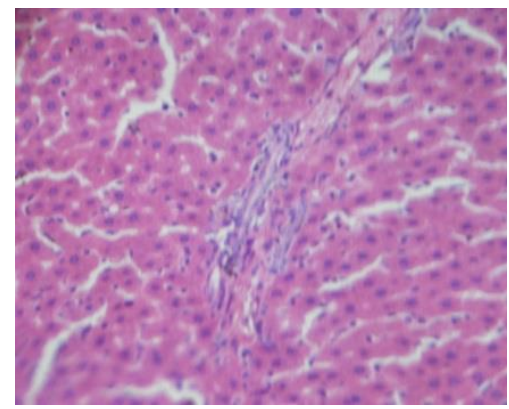

Plate 4: Cross section of the liver of PCOS rats administered $50 \mathrm{mg} / \mathrm{kg}$ body weight of aqueous extract of $P$. nigrescens leaves $(\times 40: \mathrm{H} \& \mathrm{~F})$

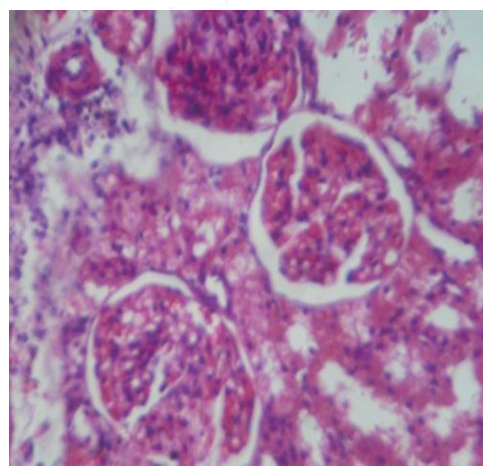

Plate 7: Cross section of the kidney of female rats administered distilled water $(\times 40 ; \mathbf{H} \& \mathbf{E})$.

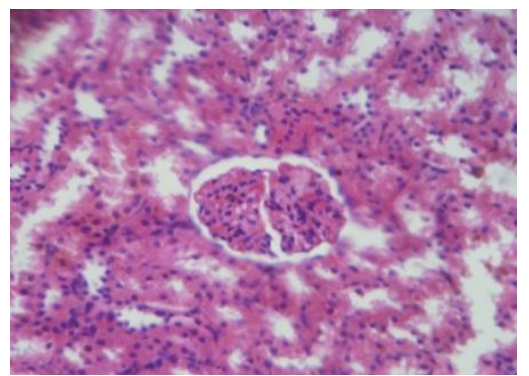

Plate 10: Cross section of the kidney of PCOS administered $50 \mathrm{mg} / \mathrm{kg}$ body weight of aqueous extract of $P$. nigrescens leaves $(\times 400 ; \mathrm{H} \& \mathrm{E})$

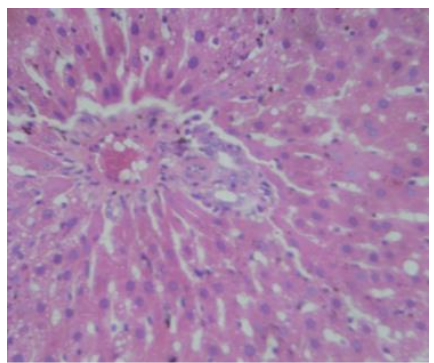

Plate 2: Cross section of the liver of PCOS rats administered $0.5 \mathrm{ml}$ of distilled water $(\times 40 ; H \& E)$

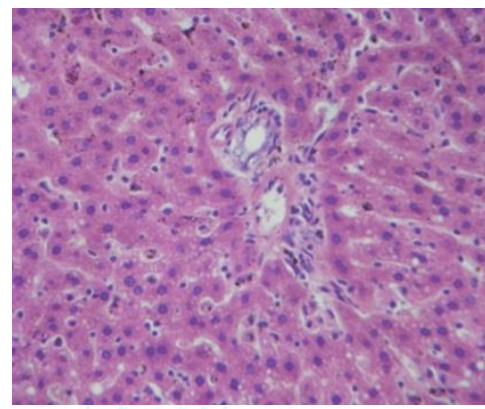

Plate 5: Cross section of the liver of PCOS rats administered $100 \mathrm{mg} / \mathrm{kg}$ body weight of aqueous extract of $P$. nigrescens leaves $(\times 40 ; \mathrm{H} \& \mathrm{E})$

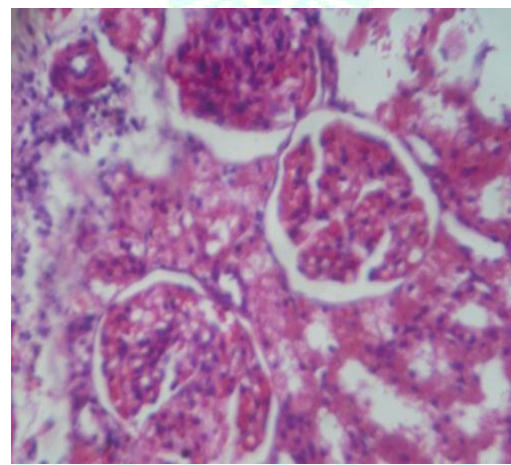

Plate 8: Cross section of the kidney of PCOS rats administered $0.5 \mathrm{ml}$ of distilled water $(\times 400 ; \mathrm{H} \& \mathrm{E})$

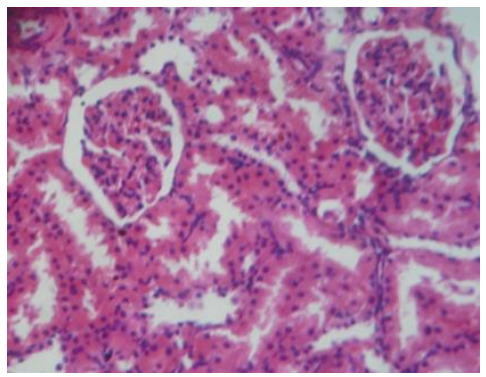

Plate 11: Cross section of the kidney of PCOS administered $100 \mathrm{mg} / \mathrm{kg}$ body weight of aqueous extract of $P$. nigrescens leaves $(\times 400 ; \mathrm{H} \& \mathrm{E})$

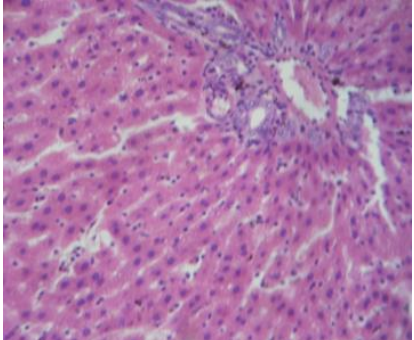

Plate 3: Cross section of the liver of PCOS rats administered 7.14 $\mathrm{mg} / \mathrm{kg}$ body weight of metformin $(\times 40 ; H \& E)$

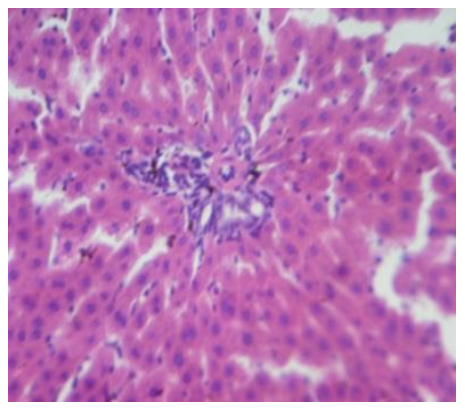

Plate 6: Cross section of the liver of PCOS reated rats administered 200 $\mathrm{mg} / \mathrm{kg}$ body weight of aqueous extract of $P$. nigrescens leaves $(\times 40$; H \& E)

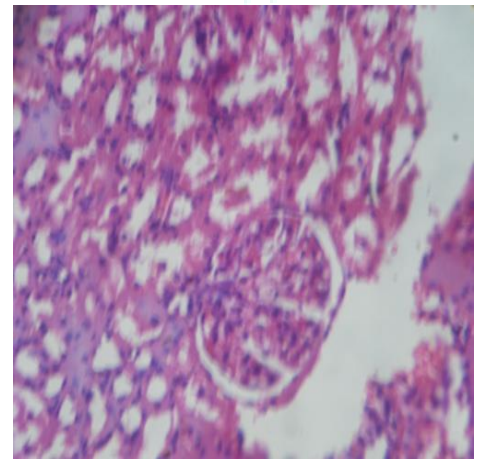

Plate 9: Cross section of the kidney of PCOS rats administered $7.14 \mathrm{mg} / \mathrm{kg}$ body weight of metformin $(\times 400 ; H \& E)$

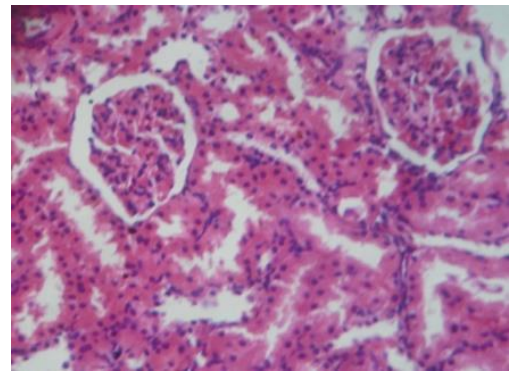

Plate 12: Cross section of the kidney of PCOS rats administered 200 $\mathrm{mg} / \mathrm{kg}$ body weight of aqueous extract of $P$. nigrescens leaves $(\times 400$; H \& E) 


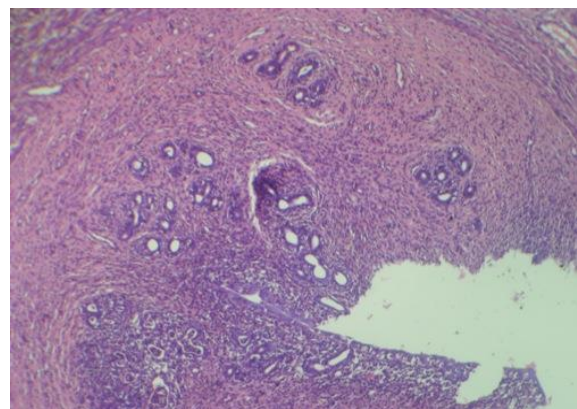

Plate 12: Cross section of the uterus of female rats administered distilled water $(\times 40 ; \mathrm{H} \mathrm{\&} \mathrm{E})$

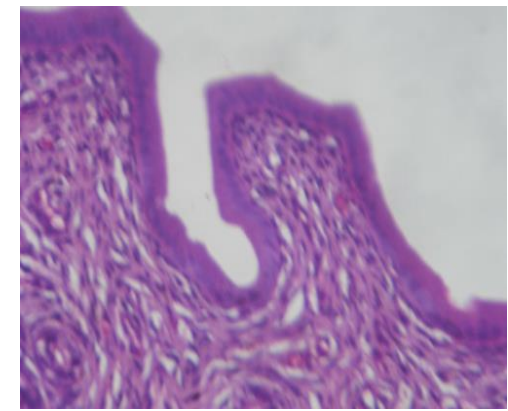

Plate 14: Cross section of the uterus of PCOS rats administered distilled water (×10; H \& E)

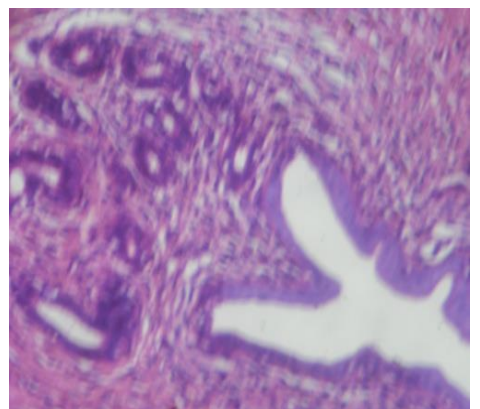

Plate 15: Cross section of the uterus of PCOS rats administered $7.14 \mathrm{mg} / \mathrm{kg}$ body weight of metformin $(\times 10 ;$ H \& E)

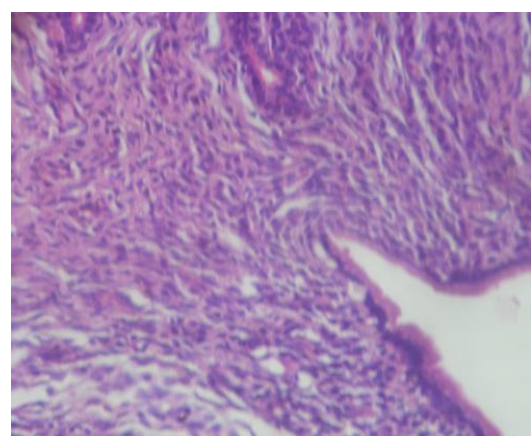

Plate 16: Cross section of the uterus of PCOS rats administered $50 \mathrm{mg} / \mathrm{kg}$ body weight of aqueous extract of $P$. nigrescens leaves $(\times 10 ; \mathrm{H} \& \mathrm{E})$

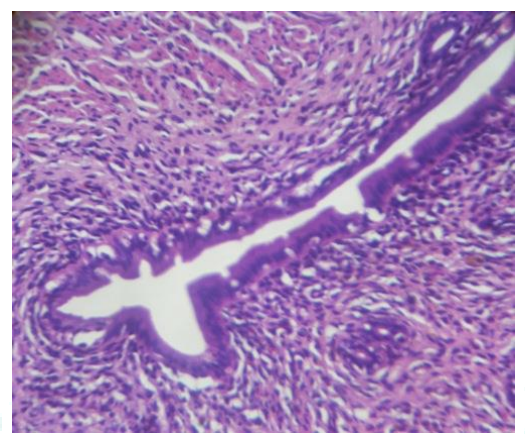

Plate 17: Cross section of the uterus of PCOS rats administered $100 \mathrm{mg} / \mathrm{kg}$ body weight of aqueous extract of $P$. nigrescens leaves $(\times 10 ; \mathrm{H} \& \mathrm{E})$

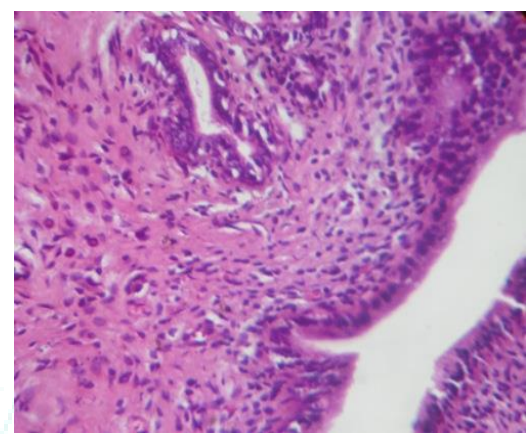

Plate 18: Cross section of the uterus of PCOS rats administered $200 \mathrm{mg} / \mathrm{kg}$ body weight of aqueous extract of $P$. nigrescens leaves $(\times 10 ; \mathrm{H} \& \mathrm{E})$

\section{DISCUSSION}

The toxicological evaluation of aqueous extract of Parquetina nigresens leaves on mifepristone-induced polycystic ovarian syndrome in female Wistar rats has provided additional information on its effects on the liver and kidney of the animals. The importance of evaluating the levels of albumin, globulin, and bilirubin (total and conjugated) in the serum of animals following the administration of chemical compounds including this plant extract cannot be overemphasized as they are useful criteria for assessing not only the secretory ability and or functional capacity of the liver but also the types of liver damage [29]. Albumin, total bilirubin and globulin which constitute protein content of the cell can be used to assess the functional capacity of the liver [30]. Furthermore, the changes in the concentrations of albumin, globulin and bilirubin in the serum of the animals can serve as useful indicators of the synthetic and secretory function of the liver and can also be used to ascertain the type of liver damage [31] [29]. The reduction in the level of conjugated bilirubin and computed albumin-globulin ratio by mifepristone in this present study may be attributed to mifepristone diminishing the biosynthesis of the conjugated bilirubin and albumin-globulin ratio The elevated level of albumin, globulin and total bilirubin may further corroborate the mifepristone treatment related changes in the female rats. The extract at $100 \mathrm{mg} / \mathrm{kg}$ body weight completely restored/reversed the elevated total bilirubin and globulin induced by mifepristone. The absence of changes in total protein level by mifepristone and all the doses of the extract suggest that the ability of the liver to produce protein was not compromised by the animals. The elevated albumin level by mifepristone was further aggravated by the administration of the extract suggesting a possible synergistic action between the drug and the extract in this study. This might be an indication that the extract also has the ability to further alter the biochemical changes initiated by the drug, mifepristone, in this instance. Overall, the mifepristone-induced functional toxicity was further aggravated by the extract in the present study.

The kidney removes metabolic wastes such as urea, uric acid, creatinine, ions and thus maintains the optimum chemical composition of body fluids [32]. Blood urea and creatinine are considered significant markers of renal dysfunction since the concentrations of these metabolites increase in the blood during renal diseases, renal damage and/or impaired kidney functions [33]. Renal function and physiologic reserve involve the ability of the kidney not only to filter and clear unwanted substances but also reabsorption of essential nutrients [2]. The absence of changes in urea and uric acid levels of mifepristone-treated rats suggest that glomerular filtration rate was unaffected by mifepristone and the administration of the extract at $50 \mathrm{mg} / \mathrm{kg}$ body weight and $200 \mathrm{mg} / \mathrm{kg}$ body weight did not induce glomerular filtration dysfunction. The elevated urea content of mifepristonetreated animals that received $100 \mathrm{mg} / \mathrm{kg}$ body weight of the extract suggests that the extract at this dose might enhance or stimulate the synthesis of urea. The elevated uric acid level of mifepristone-treated female rats that were administered the 50 and $100 \mathrm{mg} / \mathrm{kg}$ body weight of the extract suggests the extract at these doses might enhance uric acid synthesis and reduce its elimination from the body of the animals. All these alterations by mifepristone and the extract implies an effect on the normal functioning of the kidney arising probably from interference with the metabolic process of the metabolites, inefficient filtration by the kidney and obstruction of the lower urinary tract, impaired glomerular and tubular reabsorption [29]. 
Alkaline phosphatase is an ectoenzyme of the plasma membrane and is used to assess the integrity or damage to the plasma membrane [34] [35]. A significant reduction in the liver ALP activities by the administration of mifepristone without a corresponding increase in the activity of the enzyme in the serum, could be attributed to either inhibition of the enzyme activity at the cellular/molecular level [35], or inactivation of the enzyme molecules in situ [36]. The significant reduction by all the doses of the extract on ALP activity without a corresponding increase in the activity of the enzyme in the serum reveals that the extract also has a diminishing effect on ALP activity in a manner similar to the effect of mifepristone. Elevation of kidney ALP in animals administered mifepristone suggest induction of enzymes synthesis in the kidney probably by de novo or loss of other proteins from the tissues [36] and the administration of 50 and $200 \mathrm{mg} / \mathrm{kg}$ body weight of the extract with corresponding decrease in serum ALP suggests that the extract also has the potential of further inducing ALP synthesis in the kidney.

The absence of an effect on the liver and serum ALT activity of animals administered mifepristone suggests that the compound has no damaging effect on the hepatocytes. The reduction in the liver ALT in mifepristone-treated animals administered all the doses of the extract shows that the extract attenuated ALT activity and this may be due to inactivation of the enzyme molecule while the increase in the serum enzyme at 50 and $100 \mathrm{mg} / \mathrm{kg}$ body weight of the extract may be due to the contribution probably from other organs not investigated in the present study.

The significant reduction in liver AST activity without corresponding change in serum AST activity of female rats treated with mifepristone suggests enzyme inactivation by the compound. The further mitigation of liver AST by the administration of all the extract doses to mifepristonetreated rats suggest enzyme inactivation while the increase in serum AST at 50 and $100 \mathrm{mg} / \mathrm{kg}$ body weight of the extract suggest that the extract at these doses can elevate the diminished mifepristone-induced AST activity and this could be due to contribution probably from other organ not investigated.

Histological observations provide a microscopic picture of the effects produced by the interactions of the phytochemicals with the body cells [37]. The preserved liver architecture in animals treated with mifepristone suggests no structural alteration of the hepatocytes and the administration of all the doses of the extract did not compromise the hepatocellular structural integrity. The absence of gross abnormality or histopathological changes following the administration of mifepristone and the aqueous extract of $P$. nigrescens leaves to animals suggests that there was no treatment-related structural changes in the liver, kidney and uterus.

\section{CONCLUSION}

In conclusion, AEPNL aggravated mifepristone-treatment related increases in albumin, total protein and liver aspartate aminotransferase activity and reduced the increases in globulin, total bilirubin, urea, creatinine, liver and serum alkaline phosphatase and alanine aminotransferase activities. However, the $100 \mathrm{mg} / \mathrm{kg}$ body weight of the extract attenuated the effect of mifepristone on the liver and kidney of the female Wistar rats and there is no treatmentrelated histoarchitectural changes occurred in the liver, kidney and uterus of the female rats.

\section{REFERENCES}

1. Joshia, S. C., Aksha, S. and Mridula, C. Antifertility potential of some medicinal plants in males: An overview. Int. J. Pharm. Pharm. Sci. 2010; 3(5):204-217

2. Yakubu, M. T. and Nurudeen, Q. O. Toxicological effects of aqueous extract of Cnestis ferruginea (Vahl ex DC) root in paroxetine-induced sexually impaired male rats. J. Investig. Biochem. 2014; 3(5):39-45

3. Ugwu, G. O., Iyoke, C. A., Onah, H. E. and Mba, S. G. Prevalence, presentation and management of polycystic ovary syndrome in Enugu, south east Nigeria. Niger. J. Med. prac. 2013; 22(4):313-316

4. Goldenberg, N. and Glueck, C. Medical therapy in women with polycystic ovary syndrome before and during pregnancy and lactation. Minerva Ginecol. 2008; 60(1):63-75,

5. Pachiappan, S., Matheswaran, S., Saravanan, P. P. and Muthusamy, G. Medicinal plants for polycystic ovary syndrome: A review of phytomedicine research. Int. J. Herb. Med. 2017; 5(2):78-80

6. Schlage, C. Medical plants of the wasambas (Tanzania): Documentation and Ethnopharmacological evalution. Plant Biol. 2002; 2:83-92.

7. Moghetti, P., Castello, R., Tosi, F., Caputo, M., Zanolin, E., Muggeo, M. and Muggeo, M. Metformin effects on clinical features, endocrine and metabolic profiles, and insulin sensitivity in polycystic ovary syndrome: a randomized, double-blind, placebo-controlled 6-month trial, followed by open, long-term clinical evaluation. J. Clin. Endocrinol. 2000; 85:139-146,

8. Tang, T., Lord, J. M., Norman, R. J., Yasmin, E. and Balen, A. H. Insulin sensitizing drugs (metformin, rosiglitazone, pioglitazone, D-chiro-inosital) for women with polycystic ovary syndrome, oligoamenorrhoea and sub-fertility. Cochrane Database Syst. Rev. 2012; 5:30-53

9. Olayinka, O. L., Eltahir, A. G. K., Atunwa, S. A., Abdullaahi, A. A., Salawu, M. K., Ogunwale, K. A. T., Olalere, F. D., Lawal, S. A., Abdulrafiu, M., Olutunde, O. A., Afolabi, O. O. and Nafiu, A. B. Safety and toxicity of aqueous leaf extracts of Camellia sinensis, Parquetina nigrescens and Telfairia occidentalis in mice. Afr. J. Pharm. Pharmaco. 2018; 12(18):208-220

10. Bateman, J., Chapman, R. D. and Simpson, D. Possible toxicity of herbal remedies. Scott. Med. 1998; 43:7-15

11. Ernst, E. Harmless herbs? A review of the recent literature. Am. J. Med. 1998; 104:170-178

12. Awodele, O., Amagon, K. I, Wannang, N. N, Aguiyi, J. C. Traditional medicine policy and regulation in Nigeria: an index of herbal medicine safety. Curr. Drug Safe. 2014; 9(1):16-22

13. Saad, B., Azaizeh, H., Abu-Hijleh, G. and Said, O. Safety of traditional arab herbal medicine. Evid.-Based Complementary Altern. Med. 2006; 3:433-439.

14. Chang, I. M. Toxicity of herbal drugs, International Forum on Research and Development for Procedures involving Risk Assessment of Toxic Chemicals. In: Korean Society of Toxicology. Chang, I. M and Park, C. W. (ed.s). 1987; 243-257.

15. Isbrucker, R. A., Edwards, J. A., Wolz, E., Davidovich, A. and Bausch, J. Safety studies on epigallocatechin gallate (EGCG) preparations. Part 2: dermal, acute and short-term toxicity studies. Food Chem. Toxicol. 2006; 44:636-650.

16.Irvine, F. R. Woody plants of Ghana with special reference to their uses. Oxford University Press. London. 1961; 19-20:695.

17. Agbor, G. A. and Odetola, A. A. Effect of Parquetina nigrescens on erythrocyte indices and serum electrolytes of rats following acute blood loss. Pak. J. Biol. Sci. 2005; 8:527-531.

18. Burkill, H. M. The useful plants of West Tropical Africa. 1985; $4 \& 8$

19. Fong, H. H. S., Tin-Wa, M. and Farnsworth, N. R. Cytotoxic principles of Parquetina nigrescens (Afzel.) bullock (Asclepiadaceae). J. Pharm. Sci. 1995; 64(10):1674-1676.

20. Agbor, A. G. and Odetola, A. A. Hematological studies of Parquetina nigrescens haemorrhagic anaemic rats. Afr. J. Med. Med. Sci. 2001; 30:105-109.

21. Kayode, O. T. and Yakubu, M. T. Parquetina nigrescens leaves: chemical profile and influence on the physical and biochemical indices of sexual activity of male Wistar rats. J. Integr. Med. 2017; 15(1):64-76

22. Saba, A. B., Oyagbemi, A. A. and Azeez, O.I. Antidiabetic and haematinic effects of Parquetina nigrescens on alloxan induced 
type-1 diabetes and normocytic normochromic anaemia in Wistar rats. Afr. Health Sci. 2010; 10(3):276-282

23. Datté a Jacques, Y., Zieglera, A. and Tillementb, J. Sympathomimetic effects of Parquetina nigrescens (Periplocaceae) extract in isolated portal vein smooth muscle. Gen. Pharmacol. 1999; 32(5):551-556

24. Yakubu, M. T., Olawepo, F. J., Olayaki, L. A. and Ibrahim, O. O. K. Mifepristone (RU486) induces polycystic ovarian syndrome in female Wistar rats with features analogous to humans. J. Endocrinol. Reprod. 2015; 19(1):40-51

25. Yakubu, M. T., Akanji, M. A., Oladiji, A. T., Olatinwo, A. O., Adesokan, A. A., Yakubu, M. O., Owoyele, B. V., Sunmonu, T. O. and Ajao, M. S. Effect of Cnidoscolous aconitifolius (Miller) I.M. Johnston leaf extract on reproductive hormones of female rats. Iran J. Reprod. Med. 2008; 6(3):149-155

26. Tietz, N. W., Pruden, E. L. and Siggaard-Anderson, O. Tietz Textbook of Clinical Chemistry. In: Burtis, C. A., and Ashwood, E. R. (ed.s). W. B. Saunders Company, London. 1994; 13541374.

27. Krause, W. J. The Art of Examining and Interpreting Histologic Preparations. A Student Handbook. Partheton Publishing Group, United Kingdom. 2001; 9-10, 24

28. Drury, R. A. and Wallington, E. A. In: Carleton's Histological Techniques. 4th ed. Oxford University Press, New York. 1973; 58

29. Yakubu, M. T., Bilbis, L. S., Lawal, M. and Akanji, M. A. Effect of repeated administration of sildenafil citrate on selected enzyme activities of liver and kidney of male albino rats. Niger. J. Pure Appl. Sci. 2003; 18:1395-1400

30. Ganong, W. F. Review of Medical Physiology. 20th ed. Lange Medical Books, London. 2001; 414-417.

31. Kaplan, A., Szabo, L. V. L. and Opheim, K. E. Clinical Chemistry: Interpretation and Techniques: Lea and Febiger Philadelphia. xvii, 1979; 440 p. : ill.

32. Taubert, D., Roesen, R. and Schömig, E. Effect of cocoa and tea intake on blood pressure: meta-analysis of randomized controlled trials. Arch. Intern. Med. 2007; 167(7):626-634

33. Shaffiee, M. A., Akbarian, F., Memon, K. K., Aarabi, M. and Boroumand, B. Dermatologic Manifestations in End-stage Renal Disease. Iran J. Kidney Dis. 2015; 9(5):1-15

34. Shahjahan, M., Sabitha, K. E., Jamu, M. and Shyamala-Dev, C. S. Effect of Solanum trilobatum against carbon tetrachloride induced hepatic damage in albino rats. Indian J. Med. Res. 2004; 120:194-198

35. Akanji, M. A., Olagoke, O. A and Oloyede, O. B. Effect of chronic consumption of metabisulphite on the integrity of the rat kidney cellular system. Toxicology. 1993; 81:173-179.

36. Umezawa, H. and Hooper, I. R. eds. "Aminoglycoside Antibiotics" Handbook on Experimental Pharmacology. Springer-Verlag, Berlin and New York. 1982; vol 62,

37. Owolabi, J. O. and Ogunnaike, P. O. Histological evaluation of the effects of Moringa leaf extract treatment on vital organs of murine models. Merit Res. J. Med. Med. Sci. 2014; 2(10):245257 